www.uoc.edu/idp

\title{
Legal Challenges for Online Digital Libraries*
}

\author{
Argyri Panezi \\ Ph.D. Candidate \\ European University Institute, Department of Law (Florence)
}

Published: October, 2014

\begin{abstract}
Libraries have traditionally played a central role in collecting and organizing material and giving wide access to culture and knowledge. Does the existing copyright framework provide enough space for online digital libraries to claim an equivalent central role in the online space? This article explores the legal challenges for online digital libraries' collection building. The materials that comprise the content of a library fall broadly under three categories with respect to their copyright status: copyrighted works, works with ambivalent copyright status (such as orphan and out-of-print works) and public domain works. In the paper, I try to answer a number of legal questions related to these three categories of works, inter alia licensing and e-lending as well as digital exhaustion, and also defend the value of creating and sustaining robust digital libraries online. The paper will conclude on how the theory of the commons can improve the existing legal framework and strengthen the libraries' position in order to sustain valuable knowledge commons supporting the ever-growing network ecosystem. Thus, I emphasize the value of maintaining a growing public domain that can be organized and digitally accessible online.
\end{abstract}

\section{Keywords}

digitization, EU digital policy, digital libraries, licensing and e-lending, digital exhaustion, orphan works, public domain, knowledge commons

\section{Topic}

copyright

* This article constitutes the communication presented by the author at the International Conference on Internet Law and Politics 2014, and as such was included in the Proceedings of the Conference, which are available at <http://hdl. handle.net/10609/36801〉. 


\title{
Retos legales para las bibliotecas digitales en línea
}

\begin{abstract}
Resumen
Tradicionalmente, las bibliotecas han tenido un papel central a la hora de coleccionar y organizar material, y de ofrecer un acceso amplio a la cultura y el conocimiento. ¿Ofrece el marco actual de derechos de autor espacio suficiente para que las bibliotecas digitales puedan reclamar un papel equivalente en el espacio en línea? Este artículo explora los retos legales a los que se enfrentan las bibliotecas digitales a la hora de crear colecciones. En cuanto a los derechos de autor, los materiales de una biblioteca se clasifican, en sentido amplio, en tres categorías: obras protegidas por derechos de autor, obras con un estatus ambivalente (como por ejemplo obras huérfanas o agotadas) y obras de dominio público. Este artículo intenta responder a una serie de cuestiones jurídicas relacionadas con estas tres categorías (como por ejemplo, entre otras, la concesión de licencias, el préstamo electrónico y el agotamiento de obras digitales); además, quiere defender la importancia de establecer y mantener bibliotecas digitales en línea. El documento concluye explicando de qué modo la teoría de los bienes comunes puede mejorar el marco legal existente y fortalecer la posición de las bibliotecas a fin de mantener el valioso patrimonio de conocimientos comunes que alimenta el ecosistema creciente de la red. En consecuencia, se pone de relieve la importancia de mantener un dominio público cada vez más amplio que se pueda organizar y al que se pueda acceder digitalmente en línea.
\end{abstract}

\section{Palabras clave}

digitalización, política digital de la UE, bibliotecas digitales, concesión de licencias y préstamo electrónico, obras huérfanas, dominio público, patrimonio de conocimientos comunes

\section{Tema}

Copyright

\section{Introduction: why is the discussion about digitization policy and the creation of digital libraries important?}

Why do policymakers care about digital libraries, whose purpose is mainly public, at a time when the e-book market is evolving exactly as a market, without public purpose considerations?' There are important reasons why we still need to care about libraries also in the digital age. Libraries have traditionally played a central role in collecting and organizing material and giving wide access to culture and knowledge. While a market is consumer-preference driven, culture and knowledge (scientific or academic etc.) need to be organized and preserved at times beyond markets. This is obviously the case, for example, with niche scholarship on topics as specific as medieval medical history. Thus, a task of assembling human knowledge online extends beyond the digitization of popular literature titles. All the more, the intellectual works, after being assembled, need to be curated, organized and presented in a useful way to the public. These are all tasks that libraries are traditionally committed to. Therefore, the question that this article wishes to explore further is on this very issue of the role of the digital libraries. Do existing regulatory frameworks, mainly copyright limitations and exceptions,

1. E-book readers, the need for interoperability, price-fixing, competition and dominance (see Amazon) are among the biggest issues debated today as regards the new and quickly developing e-book market See A. Daly (2013, 350 et. seq.) 
provide enough space for online digital libraries to claim an equivalent central role in the online space?

In broad terms, the two jurisdictions that I take into account are the American and the European. Digitization has been a clear priority in the EU digital agenda for some time now. ${ }^{2}$ At the same time the issue has been and continues to be heavily debated in the US in the context of the Google Books litigation and with more digital library initiatives having started in parallel. ${ }^{3}$

This article begins by mapping the relevant legal issues involved. I first explore the legal challenges for online digital libraries' collection building with regard to copyrighted works, works with ambivalent copyright status (such as orphan and out-of-print works) and public domain works. Second, I look at what is the additional value of a digital library, which should make policymakers differentiate them and perhaps entrust them with the special role of offering wide access to intellectual works and preferential treatment in the form of copyright limitations and exceptions.

\section{Legal challenges for online digital libraries' collection building}

The materials that comprise the content of a library fall under three categories with respect to their copyright status: copyrighted works, orphan works and out-of-print works. These three I categorize together as works with ambivalent or, rather, problematic copyright status (such as orphan and out-of-print works) and public domain works. A complete digital library should be able to offer access to all of these types of works.

I explore the collection that a digital library builds following this categorization since the legal status then dictates accessibility. A copyrighted book cannot be offered online without the right-holders' permission, and is accessible under their terms.
I will examine these three categories consecutively. I begin with copyrighted works. Besides being a very big corpus of works, it is also a hugely important one given that most recent books and intellectual works in general are usually under copyright. Even if some copyrighted works are freely accessible, for example under a certain type of Creative Commons license, they are still as such under the copyright framework - essentially meaning that they are not part of the public domain, unless the right-holders have explicitly given up their rights.

Starting with the copyrighted works, the questions that emerge broadly occur in two phases, one during the input phase (how does the library get access to the copyrighted material?), and the second during the output phase (in what manner is the library allowed to offer access to the public, its users?). I will look at the distribution right that copyright affords to right-holders and also exhaustion and the big debate of digital exhaustion.

Then I explore the orphan works puzzle and the issue of out-of-print works, and propose a policy solution or change that strengthens the case for digital libraries: entrusting the orphans and the out-of-print works to the public domain. Last, I examine the public domain works and whether the legislator (the copyright policymaker) indeed promotes access and reuse of this category of materials. I conclude by arguing how digital libraries could be the institutional gatekeepers of these bodies of works managed primarily (where possible) as commons.

\section{Copyrighted works}

\subsection{Distribution right and exhaustion}

Two central economic rights that copyright affords to rightholders are, first and foremost, the reproduction right (right to make copies) and, second, the right to distribution (right to distribute copies). ${ }^{4}$ The right to distribute copies is relevant

2. The legal bases thus far are mostly soft law provisions: Commission and Council recommendations and conclusions (article 292 TFEU), press releases and reports (such as the Comité des Sages report) and some specific legislation initiated (notably the Orphan Works Directive). Most importantly, though, the ongoing copyright reform consultation (public consultation on the review of the EU copyright rules) can potentially play a big role further producing hard law changes with direct effects on digitization and the creation of libraries online. For the EU's digital libraries initiative see: 〈http://ec.europa.eu/information_society/activities/digital_libraries/index_en.htm〉.

3. See primarily the Digital Public Library of America (DPLA). For the ongoing efforts of the US Copyright Office - and also the legislation it seeks to implement, for example on the issue of orphan works see 〈http://www.copyright.gov/orphan/> (ongoing inquiry).

4. P. Goldstein and B. Hugenholtz (2013, pp. 307- 321) 
to the discussion of library lending and, by consequence, to e-lending as well (following subchapter).

Article 6 of the WIPO Copyright Treaty is devoted to the Right of Distribution and states that:

1) Authors of literary and artistic works shall enjoy the exclusive right of authorizing the making available to the public of the original and copies of their works through sale or other transfer of ownership.

(2) Nothing in this Treaty shall affect the freedom of Contracting Parties to determine the conditions, if any, under which the exhaustion of the right in paragraph (1) applies after the first sale or other transfer of ownership of the original or a copy of the work with the authorization of the author.

(emphasis added)

As demonstrated in the wording of the above Article 6 in paragraph 2, the distribution right is limited by exhaustion (principle of exhaustion or first sale doctrine). Once copies of works have been placed in the market with the right holder's consent, further re-distribution (for example, resale) does not need to be authorized. This is a longstanding rule in the EU jurisdictions where the principle of exhaustion has been established by the European Court of Justice and codified in the Information Society Directive of 2001 article 4(2). In addition, there is a territorial effect within the entire EU jurisdiction, as first sale of a work in one EU member state will also exhaust the distribution right of the author in all other member states. In US Iaw the US Copyright Act recognizes the same rule in section 109(a).

Traditionally, once a library purchases a book from a publisher, the exhaustion or first-sale doctrine releases the copy from further copyright control. ${ }^{5}$ Library lending of printed books finds its legal basis exactly on this doctrine. This is not the case today for e-books and e-lending. According to the Agreed Statements concerning the WIPO Copyright Treaty (statements concerning Articles 6 and 7), the expressions copies and original and copies, subject to the right of distribution and the right of rental under the said Articles, refer exclusively to fixed copies that can be put into circulation as tangible objects. ${ }^{6}$

Thus, currently copyright law worldwide explicitly only grants exhaustion to tangible objects, such as printed books. ${ }^{7}$ The situation for digital works, including e-books, is unclear. According to Harald Müller, from a legal point of view libraries cannot lend e-books out because there is no statutory legal instrument available for e-book loan services by libraries. ${ }^{8}$ I am not entirely certain that this conclusion holds unconditionally. This author, however, suggests that since the current regulatory framework does not protect libraries, as exhaustion does for printed books, they must lobby to create new legal instruments enabling e-lending.

\subsection{Licensing and e-lending}

Given the lack of clear regulatory framework covering e-lending, libraries that wish to make e-books available for lending to their users are currently facing several licensing practices and models offered by publishers or right holders. This is the case both for purely digital libraries and for traditional libraries wishing to offer digital services on top of their traditional services. The framework is still quite unclear for a number of reasons, both practical and legal. E-lending is a rather new service, which they can now offer only once they negotiate with publishers and clear licensing terms. This is quite different than what libraries are used to in terms of lending services for print books. To lend print books all libraries do, traditionally, is acquire copies, which are then part of their own collection. In the legal sense the exhaustion or first sale doctrine, as we will analyze further, has been covering the lending of print books. The situation with e-books, however, is different. Access to e-books takes place on the basis of licenses rather than purchase.

From the publishers' side, the business models for licensing are still new as they experiment with different levels of access as well as with pricing. The e-book market is rapidly

\footnotetext{
5. Ibid, p. 316. There is however a "Public Lending Right" in the European Union jurisdictions, as per the EC Rental Right Directive.

6. See 〈http://www.wipo.int/meetings/en/html.jsp?file=/redocs/mdocs/diplconf/en/crnr_dc/crnr_dc_96.html〉.

7. H. Müller (2012, p. 152).

8. Ibid.
} 
expanding ${ }^{9}$ and, as the market is expanding, publishers experiment with several digital publishing business models. David O'Brien, Urs Gasser and John Palfrey classify the models used by e-book distributors to libraries in three general categories (a distributor is usually the intermediate that sells access to e-books to the libraries, often from multiple publishers ${ }^{11}$ ): 1 . the perpetual access model, 2. the subscription model and 3. the pay-per-view model. ${ }^{12}$

The perpetual access model allows libraries to integrate e-books into their collection through an e-book collection management software platform, usually hosted not by the library itself but by an e-book vendor. ${ }^{13}$ Access is determined by the terms of each license. The DRM technology used by the vendor platform limits how the file can be accessed and shared. ${ }^{14}$ This model usually tries to replicate print book lending in that it limits access to the e-book in time (loan periods are usually between 14 and 21 days), and allows one (or some) patron at a time. The costs for this model include platform maintenance fees; in addition, e-book titles are generally more expensive compared to purchase of the print book. ${ }^{15}$

The subscription model gives the libraries the option of subscribing to a database of e-book titles for a predetermined period of time. ${ }^{16}$ Upon termination of the subscription the library no longer has access to the database unless it renews its subscription. The advantage of this model is that an unlimited number of patrons can access the same e-book simultaneously. However, the cost per user for the library is quite high. Another disadvantage is that vendors avoid offering front list titles (publisher's list of new titles) with this model. ${ }^{17}$

In the pay-per-view model, used less frequently than the other two, libraries pay a certain fee in order to display a list of available titles to their users. ${ }^{18}$ With every use of each title, however, the library needs to pay an additional fee per copy. The flat fee for accessing the e-book list is much lower compared to the subscription model but then the renting fee per copy rises.

There is also a patron-driven acquisition model, which resembles the pay-per-view model. If a predetermined number of patrons request a certain book title, the library will acquire a copy from the distributor. ${ }^{19}$ The difference here is that libraries actually acquire ownership of the titles unlike with the pay-per-view model.

Upon first examination, these models have a number of advantages and disadvantages. Access to front list titles is one common problem. Balancing the costs of the model

9. Notably in 2011 Amazon.com officially announced that it sells more kindle books than print books. Amazon press release: <http://phx. corporate-ir.net/phoenix.zhtml?c=176060\&p=irol-newsArticle\&ID=1565581\&highlight>.

See also: 〈http://www.nytimes.com/2011/05/20/technology/20amazon.html〉.

In 2012 Amazon.co.uk made the same announcement. See <http://www.theguardian.com/books/2012/aug/06/amazon-kindle-ebook-salesovertake-print>.

At the same time, not all publishers permit e-book lending in libraries. Some see libraries as competitors in the digital distribution of books and do not offer library e-lending programs. Among big publishers that allow e-book lending are Random House, Penguin, Hachette and HarperCollins, (David O'Brien et al., p. 9). Notably Simon \& Schuster did not license any e-books and only in April announced a one year pilot program with New York libraries, see <http://www.forbes.com/sites/davidvinjamuri/2013/04/15/simon-schuster-tests-ebook-lendingwith-new-york-libraries/>.

10. David O'Brien, et al. Urs Gasser, John Palfrey, E-Books in Libraries: A Briefing Document Developed in Preparation for a Workshop on E-Lending in Libraries, Berkman Center Research Publication No. 2012-15, available at 〈http://papers.ssrn.com/sol3/papers.cfm?abstract_id=2111396\#\#〉, page 8.

11. The most commonly used distributors from the US libraries are OverDrive, NetLibrary, Gale/Cengage and EBSCOhost. Ibid (O'Brien, Gasser \&Palfrey), also citing Library Journal E-book Survey in "Ebooks the New Normal: Ebook Penetration \& Use in US Public Libraries", Library Journal, 2011, p.24, available at <http://www.thedigitalshift.com/research/>.

12. O'Brien, Gasser \& Palfrey (2012, p. 10).

13. Ibid, p. 14.

14. Ibid.

15. Ibid, p. 15.

16. Ibid, p. 17.

17. Ibid.

18. Ibid, p. 19.

19. Ibid, p. 11. As the authors explain, this model is very useful for libraries offering bestselling e-books that are in high demand. 
with the patrons' usage (demand) is probably the most difficult issue. The most problematic aspect is that as long as these models offer licensing rights and not ownership to the libraries, access is always subject to the libraries' ability to pay fees (which are a form of subscription fees). Without clear ownership, the libraries' abilities to build, maintain and curate a collection is substantially discounted. The advantage of these models is their flexibility. Publishers, intermediaries and libraries can collaborate to adjust packages to needs and to user's demands. This is at least true in theory, bearing also in mind, however, the negotiating power of each party. Copyright holders might be nervous that the ease of use of a digital library will mean that consumers will stop buying books (cannibalization of sales). While physical books degrade, thus the second-hand markets are less of a threat to the first-hand markets; it is true that digital books don't degrade. Thus, the negotiation and contracting process for copyrighted works between libraries and active right holders is not simple, as the latter will be looking for revenue streams and perhaps the maximum possible profit. ${ }^{20}$ All the more is the case with their collective societies.

\subsection{Legal constructions proposed to address the problem}

In view of the above described situation, scholarship looks at copyright theory (and beyond it) to discover the solutions to legal obstacles that libraries are currently facing with e-lending and formulate arguments on how to also apply the exhaustion or first-sale doctrine to digital works.

\section{a.) Legislative amendment of copyright law/ special library exemption}

Legislative history of the US first-sale doctrine legislation shows that library lending is one of the underlying reasons for the existence of the doctrine. ${ }^{21} \mathrm{~A}$ similar rationale can be traced in the various EU jurisdictions and the copyright exceptions they provide for libraries. ${ }^{22}$ Yet, given the lack of legislative provisions that address the same issue for digital works and the lack of any explicit legislative exemption for libraries as regards e-lending, some scholars argue that there is a need for new legislative action. The United States Copyright Office had reached an analogous conclusion in a policy document in 2011.23 According to the Copyright Office, section 108 of 17 U.S.C. enacted in 1987 "was shaped by the technology and concerns of the pre-digital age."24 The appropriate scope of library exceptions might, thus, need to be revisited in a coherent and systematic manner.

During the summer of 2013 the Dutch association of public libraries (Vereniging van Openbare Bibliotheken (VOB)) initiated a test case in their national court of first instance about the right to lend e-books in public libraries. ${ }^{25}$ The libraries assert that e-lending is (or should be) included in the copyright exception for libraries and ask for a preliminary reference to be sent to the European Court of Justice. The Minister of Education, Culture and Science, on the basis of a special report prepared by the IVIR Institute (Institute for Information Law at the University of Amsterdam), already denied such right. ${ }^{26}$ The report observed that e-lending already occurs in public libraries in several jurisdictions and is not based on copyright limitations or exceptions, but proceeds on the basis of contractual agreements. The central question that the report posed was "whether e-lending by public libraries is covered by the existing public lending right regime of the Dutch Copyright Act (Auteurswet), and whether the European copyright framework leaves enough space for a copyright limitation or exception at the national level."27 Both questions were answered negatively.

The recent Dutch report on online e-book lending through libraries ${ }^{28}$ adds that the Copyright Directive of 2001 provides for an exhaustive list of permitted limitations and exceptions to copyright, including several exceptions that concern public libraries. It stresses that the existing European copyright framework, in its current state, does not leave room for

\footnotetext{
20. R. C. Picker (2011, p. 9).

21. M. Chiarizio (2013, p. 620).

22. P. Goldstein and B. Hugenholtz (supra note 4, p. 316).

23. US Copyright Office (2011, pp. 19-22).

24. Ibid, p. 20

25. See: 〈http://www.futureofcopyright.com/home/blog-post/2013/06/18/dutch-public-libraries-are-commencing-a-test-case-on-e-lending.html〉.

26. The report entitled "Online uitlenen van e-books door bibliotheken" (Online lending of e-books through libraries) is available in Dutch at: 〈http://www.ivir.nl/publicaties/poort/Online_uitlenen_van_e-books.pdf〉 and includes a summary in English.

27. Ibid.

28. The Dutch report, supra note 26.
} 
the introduction at the national level of a (compensated or non-compensated) copyright exception permitting online lending of e-books by public libraries. ${ }^{29}$

As we noted above, one can conclude that libraries need to lobby for a statutory solution for their e-book activities..$^{30}$ For that reason they need to lobby in order to secure that the privileges they enjoy as institutions in the analogue world are also enjoyed in the digital world. Indeed, libraries already do that. The International Federation of Library Associations (IFLA) for example has taken the lead with a concrete treaty proposal on limitations and exceptions for libraries and archives. ${ }^{31}$

\section{b.) Courts' intervention to uphold digital exhaustion}

Other scholars are more skeptical about the possibility and practicability of a legislative solution. ${ }^{32}$ Nevertheless, as copyright law has strong roots in judicial construction, with most doctrines originating in common law case law, these scholars trust that the courts can effectively manage the new challenges that the digital era poses to libraries. These would include e-lending.

Aaron Perzanowski and Jason Schultz observe that with the shift towards digital markets the first sale doctrine is increasingly marginalized. ${ }^{33}$ They suggest that courts should remedy that, since a legislative change towards this end is difficult or unlikely to occur today. In their article on digital exhaustion the authors argue that the common law judge (they are writing in the setting of the US jurisdiction) can apply a broader principle of copyright exhaustion to which first sale is part. This broader principle, as emerges from several cases, guarantees a set of privileges for the user, namely alienation, renewal, repair, adaptation and preservation. ${ }^{34}$
Judges are called to apply the exhaustion principle to digital copies as they already do to computer programs (17 USC section 117). According to Perzanowski and Schultz courts are already empowered to do so. ${ }^{35}$ It is important that the benefits of the first sale doctrine are also enjoyed for digital works (as functionally equivalent privileges ${ }^{36}$ ). The reasons for this are traced in the benefits of the first sale doctrine or exhaustion in general. These benefits are:

i. increased access: availability as well as affordability of copyrighted works is increased. After the first sale, the right holder lawfully loses control over the copies. Secondhand bookstores, libraries, video rental shops and auctions sites are then able to operate as a secondary market which accelerates access and pushes prices down so that they are affordable to audiences that would otherwise not be consumers in the primary market. ${ }^{37}$

ii. preservation: specifically for works that are no longer commercially interesting, as for example out-of-print books or orphan works; the first sale doctrine assists in maintaining circulation and thus preserving and keeping cultural products alive. ${ }^{38}$

iii. privacy: consumer privacy and anonymity are threatened when right holders preserve control over the circulation of their work after the first sale has occurred..$^{39}$ Reader privacy is an important issue when it comes to e-lending and the question is who controls the data that reveals reading habits of users; libraries or private distributors that operate DRM platforms?

iv. transactional clarity: transaction costs are rendered disproportionately high and cost inefficient, when relatively low-cost copyrighted works require complex

29. Ibid, English summary.

30. Müller (supra note 7, p. 154).

31. See 〈http://www.ifla.org/node/5856〉.

32. A. Perzanowski and J. Schultz (2011).

33. Ibid, pp. 892 et seq.

34. Ibid, p. 912 and pp. 913-922 citing ample case law where the rights to repair and renewal, rights to adaptation and modification, and display and performance rights are established.

35. Ibid, p. 936.

36. Ibid, p. 937

37. Ibid, p. 894-5. The authors cite evidence that secondary markets are better at price discrimination and at maximizing social welfare than copyright owners.

See also A. Reese (2003, pp. 644- 652).

38. Ibid, p. 895.

39. Ibid, p. 896. See also J. E. Cohen (1996). 
limitations and control over redistribution after the first sale. ${ }^{40}$

v. user innovation: there is effective incentive for right holders to innovate in order to compete with secondary markets. This way, new or better creations such as updated works or additional content are promoted. ${ }^{1}$

vi. platform competition: consumer lock-in is reduced with regards to platforms, when consumers are allowed to alienate their digital purchases from the platforms and transfer them when switching platforms without the need to repurchase. ${ }^{42}$ The argument promotes interoperability; that is, for example, the ability to read the same e-book on a kindle or an iPad.

\subsection{Allowing a young market to mature through competition or intervening when contracts appear to override copyright law?}

Matthew Chiarizio notably suggests that the best course of action for the government is to not intervene but allow the stakeholders "a chance to find a solution within the existing legal framework". ${ }^{43}$ This suggestion emphasizes the still undeveloped nature of the relevant market, with a lot of potential toexperiment and innovate in viablee-lendingmodels.

The idea that any intervention would be either premature or disrupt the growth of the market does not fully address an important factor: the asymmetries in the involved parties' bargaining powers. Libraries have traditionally enjoyed privileges for a number of (valid) reasons. The challenges they face in the digital era are numerous. In a digital world where electronic retailers have started offering services such as 'Amazon's Kindle Owners' Lending Library', ${ }^{44}$ trusting the negotiating power of libraries and letting them survive the e-book market as created without any equivalent to the digital exhaustion doctrine might be too optimistic.

On the other hand, investigating the current business models for licensing that enable library e-lending, one cannot help but conclude that this is another case where contracts are claiming to supersede copyright law. The relation between the legislative exceptions and limitations to copyright and freedom of contract to restrict such exceptions and limitations in a private contract has been a difficult issue that courts as well as scholars already faced before the e-lending discussion. ${ }^{45}$ More specifically, courts have faced the issue of boundaries between ownership and licensing in several contexts. There is, for example, ample case law around computer software attempting to determine whether a transaction was a license or a sale. ${ }^{46}$

The problem with e-lending is that the major publishers, contractually superior to small libraries or, generally, libraries with serious budget limitations, are now establishing contractual conditions that exceed the monopoly afforded by copyright. ${ }^{47}$ Without the limitations that the exhaustion or first sale doctrine place on the copyright monopoly of the right holders, distribution of digital works circumvents the rationale behind copyright (to guarantee enough, but not more than that, incentives for creation) and promotes rent-seeking practices.

Copyright law claims the ability to maintain the delicate balance between different interests. The various exceptions

40. Ibid, p. 896.

41. Ibid, p. 897.

42. Ibid, pp. 900-901.

43. Chiarizio, supra note 21, p. 641.

44. See 〈http://www.amazon.com/gp/feature.html?docld=1000739811〉.

See also B. Rosenblatt (2012).

In view of Amazon's launching of a lending library, Lloyd Jassin interestingly finds that the next great e-book debate will be on how to define subscription revenue. See Lloyd Jassin, Amazon's Lending Library Liability, available at <http://www.copylaw.org/2011/11/amazonslending-library-liability.html>.

45. See O. Fischman Afori (2013, p. 401)

46. From US case law see:

Vernor v. Autodesk Inc.,621 F.3d 1102, 1110-11 (9th Cir. 2010)

MDY Industries. v. Blizzard Entertainment, Inc., 629 F. 3d 928, 938 (9th Cir. 2010)

Apple, Inc. v. Psystar Corp., 658 F.3d 1150, 1155-56 (9th Cir. 2011)

UMG Recordings, Inc. v. Augusto, 628 F.3d 1175, 1180 (9th Cir. 2011).

47. O. Fischman Afori, supra note 45, p. 393. 
and limitations are also attempting to maintain the same balance. When contracts afford benefits to right holders that far exceed the rights afforded by copyright law this already delicate balance is distorted. This seems to be the case with licensing models that publishers currently offer to libraries. Academic libraries in particular are suffering from this development. Restrictive licenses then threaten to become a real obstacle to research and teaching. ${ }^{48}$ This also explains the spread of the open access movement and the role that major libraries seek to play leading the policy debate and demanding that electronic subscriptions must be rethought. ${ }^{49}$

In all, the sticking contradiction to the right holders' legal rights regarding a print book renders the need for clarity in the regulatory framework for e-lending pressing. The increased cost for online versions of works is a burden that we cannot just assume that libraries will simply adapt to. As Reese explains, a decline in affordability and of access via libraries is a crucial problem. ${ }^{50}$ Under the current framework he identifies a possibility that either digital works will be made available by libraries at greater cost or, even worse, many works will not be available in libraries at all. ${ }^{51}$ If we value the role of the library and wish to preserve it in the digital era as well, the situation is alerting and calls for regulatory action.

\section{Orphan and Out-Of-Print Works}

\subsection{The Orphans Puzzle}

Fay Kanin, Chair of the Library of Congress National Film Preservation Board (NFPB), coined the term orphan works to inclusively describe works protected under copyright whose copyright holder cannot be identified or located.
According to one account, there are two approaches in definitions to the orphan works problem. ${ }^{52}$ The first focuses on the inability of a potential user to identify and locate the right holder from whom permission is to be sought. The other approach places the inability of the user to easily obtain permission to use a particular work central to the problem (broader approach, also argued by Google during the Google Books controversy). Out-of-print books, for example, are a category, which includes orphan works, without the two categories overlapping. This broader issue of the inability or difficulty to connect to the copyright owners has led to the perception of orphan works as a greater problem of market failure. ${ }^{53} \mathrm{~A}$ potential user faces disproportionate transaction costs to obtain authorization from a right holder, as well as the risk of infringement liability. Thus, he will usually forgo the use "even though had the user been able to locate the copyright owner, a deal would have been struck for that use." ${ }^{54}$ Although it is to be expected that rights clearance involves certain transaction costs, with orphan works these costs become disproportionally high and results are still not guaranteed.

According to librarians, there are a great number of orphan works for which it is estimated that even after extensive research, no further information can be found. However, knowing the exact size of the problem is important in order to be able to calculate the social and economic costs and benefits of possible solutions to the problem. ${ }^{55}$ The very nature of orphan works renders the finding of both firm quantitative and qualitative data a difficult task. This also explains why the size of the problem has not been calculated in a consistent manner. ${ }^{56}$

48. Ibid, p. 404.

49. See open letter from Harvard University Library: "Faculty Advisory Council Memorandum on Journal Pricing", April 17, 2012, available at 〈http://isites.harvard.edu/icb/icb.do?keyword=k77982\&tabgroupid=icb.tabgroup143448〉.

50. Reese (supra note 37, p.646).

51. Ibid.

52. D. Hansen (2011).

53. Ibid, p. 1.

54. L. Pallas Loren $(2012$, p. 3).

55. See also the JISC 2009 report, analyzing data from an online survey of over 500 organizations suggesting that many public sector organizations in the UK are themselves unsure of the extent of the problem. The report is available at <http://www.jisc.ac.uk/media/ documents/publications/infromthecoldv1.pdf>.

56. For example, the British Library has estimated that $40 \%$ of its copyrighted collections are orphan: Report of the 'Comité des Sages' reflection group pm bringing Europe's cultural heritage online, The New Renaissance, available at <http://ec.europa.eu/culture/pdf/ report_Comite_des_Sages.pdf>, p. 16.

David Drummond, Google's general counsel estimated that relatively few, under $20 \%$, of the books in the Google Books corpus will ultimately turn out to be orphan (also relying on his positive predictions for Google's project incentivizing copyright owners to come forward). See 
The root of the orphan works problem, which renders the quest for a solution from the EU and the US so difficult, is found primarily in the expansions to copyright law over the past few decades; extensions of copyright duration along with elimination of registration, renewal and notice requirement for copyright protection (these results are also due to the Berne Convention rules). As simply explained by Olive Huang, longer copyright terms create longer periods over which copyright ownership can change hands and become even more difficult to trace. ${ }^{57}$

In any event, orphan works constitute an appreciable corpus of works that need to be taken into account in any discussion about a digital library. As the Google Books and HathiTrust litigations showed, orphans are also a far from negligible stake for stakeholders.

\subsection{Legislative attempts and responses thus far}

Starting with the premise that the owner (author or subsequent right holder) is absent, there is indeed an interesting question that lingers with respect to orphan works: Why has it thus far proven so difficult to introduce reform in a property law area where owners of works are absent (thus by definition are unable themselves to lobby), while users of works lobby for reform? ${ }^{58}$

Indeed, in the US there have been two unsuccessful attempts to legislate the orphan works problem: first, with the Orphan Works Act of $2006 .{ }^{59}$ Later two other bills were introduced, the Orphan Works Act of $2008^{60}$, and the Shawn Bentley Orphan Works Act of 2008. ${ }^{61}$ There is already one report on orphan works prepared by the United States Copyright Office and published in January 2006. Indicating that there will indeed be another attempt to legislate, the United States Copyright Office recently issued a broad notice of inquiry in the Federal Register, seeking comments from the public regarding the current state of play for orphan works. ${ }^{62}$

In the EU there have been concrete policy developments with the Orphan Works Directive, 2012/28/EU, adopted the previous October. ${ }^{63}$ This directive on certain permitted uses of orphan works sets out common rules for the digitization and online display of orphan works. ${ }^{64}$ The directive applies only

Pamela Samuelson, Google Book Search and the Future of Books in Cyberspace, 94 Minn. L. Rev. 1308 (2009-2010), p. 1323 citing to the Competition and Commerce in Digital Books hearing before the House of Representatives, available at <http://judiciary.house.gov/hearings/ hear_090910.html>. At the same time for the same project Jonathan Band estimated that around 75\% of out-of-print books will remain unclaimed: See J. Band (2009, p. 294).

57. O. Huang (2006, p. 268). See also D. Hansen (2012). According to Hansen the orphan works problem may have existed in theory since copyright laws first came into effect, if one defines the problem broadly as the situation where the owner of a copyrighted work cannot be located and asked for authorization by someone who wants to use it.

In her recent article Lydia Pallas Loren argues that the problem can also be traced back to terminology. Indeed, the orphan metaphor is misleading. Loren claims that the use of the metaphor is now also causing difficulties to address the problem. She proposes the term hostage works instead. Lydia Pallas Loren, supra note 54. For the notion of the "romantic author" see Mark A. Lemley (1997).

58. See A. Katz (2012, p. 1337), where he remarkably notes: "A discussion of solutions to the orphan works problem will not be complete before addressing why has it been so challenging to find an acceptable and workable solution to this problem in the first place. The difficulty is puzzling because owners of orphan works are, by definition, absent from the debate about orphan works, and normally, when discussions about contemplated reforms do not involve those who might be directly affected by them, one could expect that reform would be easy. Specifically, one could expect that in a setting where users lobby for reform that would allow them to use orphan works, and owners of those works are absent, passing a pro-user reform (even overly pro-user) would be a breeze. Therefore, the fact that it has been difficult to find an acceptable solution, and that many of the proposed solutions involve serious impediments on using orphan works, suggests that the political economy of the orphan works problem is complicated, and that there is much at stake-not necessarily for the interests of orphan owners, but for the interests of those who speak on their behalf".

59. H.R. 5439, 109th Congress, 2nd session, 22 May 2006.

60. H.R. 5889, 110th Congress, 2nd session, 24 April 2008.

61. S. 2913, 110th Congress, 2nd session, 24 April 2008.

62. See at 〈http://www.copyright.gov/orphan/>. Collective societies seem to be taking the lead against orphan works legislation, while the academic world together with libraries (comments from librarians, associations of libraries and university libraries) are recognizing a real problem that needs comprehensive solution.

63. Available at: 〈http://ec.europa.eu/internal_market/copyright/orphan_works/index_en.htm〉.

64. Directive preamble, point 3. The Directive is complementing and without prejudice to the existing 20 September 2011 Memorandum of Understanding on key principles on the digitization and making available of out-of-commerce works: Memo available at: <http://europa. eu/rapid/press-release_MEM0-11-619_en.htm>. In order to establish whether a work is orphan the above mentioned institutions shall carry 
to works that are first published (broadcast or made publicly available by the beneficiaries) in the territory of an EU Member State. In all, the solutions that the Directive provides are quite narrow in scope since they apply to a particular class of users and uses and only to particular types of works. One could question whether there is any plausible reason to discriminate between public interest institutions and others (private/forprofit bodies). Some questions also arise with regard to the (considerable) discretion of member States with respect to the implementation of the directive. Given that the EU directive is narrow and leaves ample room for different interpretations, and that the member States have now initiated debate at a national level, it is reasonable to conclude that even after the passing of the directive the debate around orphan works is far from being closed, also in the jurisdiction of the EU.

All the more, what is important for us here is that the directive is not adequately addressing the larger issue of mass digitization. The diligent search requirement it sets (Orphan Works Directive, article 3) is neither very clear nor efficient to enable mass rights clearance for orphans. This is, however, the most important issue for the creation of digital libraries, at least as regards this body of works. Thus, the directive cannot be easily seen as solving how digital libraries can deal with orphan works, which they have to do on a mass rather than an in concreto or sporadic scale.

\subsection{Scholarly proposed solutions}

There is ample legal scholarship examining the orphan works problem. Some of this scholarship includes systematic mapping and evaluation of possible solutions to the issue. ${ }^{65}$ 66 Thus, many solutions have been proposed including centrally administered licenses (this is the Canadian system), extended collective licensing (applied in various Scandinavian jurisdictions, a system where management of rights is assigned to a collective society, which negotiates freely on behalf of owners), limited liability, meaning limiting remedies after a diligent search for right holders (this is the solution favored by the US Copyright Office in both the 2006 and 2008 attempts to legislate), statutory limitation or exception, access and reuse systems tailored to fair use, suggesting that fair use exceptions suffice to solve the problem of orphan works when applied correctly. In addition to the above categories of approaches, there is one more general category; broader policy reforms that seek to address copyright formalities and duration, and library, archive and museum privileges, while having the ability to mitigate or partially address the orphan works problem. The objectives here are: 1.) reinvigoration of copyright formalities and reduction of the effect of increased copyright duration and, 2.) reforms to library, archive, and museum privileges that would allow those institutions to provide new forms of access to the works in their collection.

\subsection{Out-of-print works}

Out-of-print or out-of-commerce works have known or traceable authors, unlike orphans. However, for systematic purposes, I include them in the same problematic as orphan works. While digitization can bring new life to these works, the efficiency argument that I will make in the following chapter works well for both, when seen as abandoned property works. Unlike the orphan works issue, which became hugely debated, especially after the Google Books litigation is the US, the literature on out-of-print works is less. There has been interesting economic analysis for potential markets for out-of-print works. ${ }^{67}$ For the purposes of this paper, however, I will deal with this issue far less extensively, and grouped with orphan works where the emphasis, also from scholarship, is based.

\subsection{A solution that strengthens the case for digital libraries: entrusting orphan and out-of-print works to the public domain}

Given both the complexity of the orphan works problem and the lack of a clear and strong policy argument to

out a diligent search according to the requirements of article 3 of the directive, keeping records of their searches on a publicly accessible online database. What constitutes a diligent search is outlined in more detail in a Memorandum of Understanding on Diligent Search Guidelines for Orphan Works. Once designated as orphan, it may be used (digitized and made available) by the institutions only in order to achieve aims related to their public-interest missions, in particular the preservation of, the restoration of, and the provision of cultural and educational access to works and phonograms contained in their collection (art. 6(2) of the Directive). The directive provides for a system of compensation if the right holder(s) is found at a later stage (article 5 of the Directive).

65. S. van Gompel and B. Hugenholtz (2010).

66. D. Hansen (2012a)

67. See for example M. D. Smith, R. Telang and Y. Zhang (2012). 
maintain their copyright status, as well as the existence of out-of-print works, which have the potential of regaining a digital life, it is arguably much more efficient and a better policy option to entrust both to the public domain. From the perspective of the creator, entitlement is lost by virtue of the creator's absence or the lack of further incentives to commercialize, and because the transaction with a user, if at all possible, has become inefficient. From the perspective of the public, I argue that there should be a mere freedom in accessing and using the orphans and out-of-print works and they should be added to the corpus of the public domain. Freeing both sooner rather than later is a solution that both avoids the utility loss of abandoned works and simultaneously generates great societal benefits by enlarging the public domain. Becoming part of the public domain's commons, orphan and out-ofprint works are not losing the connection to a supposedly father/romantic author ${ }^{68}$ but are gaining a family at large, the community enjoying them and benefiting from them, utilizing them and making them relevant.

While intellectual property law generally implies an overal analogy to property law, ironically this has not been the case with orphan or out-of-print works. In property law there are a number of rules and doctrines in both civil and common law jurisdictions that favor the loss of property once abandoned for enough time (rules on adverse possession, rules determining the faith of abandoned property etc.). The rationale behind such doctrines is to penalize neglectful owners by granting, under certain requirements, property either to other (adverse) possessors, or to the public. At the same time they seek to give property owners the incentive to be attentive to their assets. ${ }^{69}$ The irony is that in this case borrowing doctrines from property law would rather go against sustaining intellectual property rights on orphans.

My main argument, however, is that the body institutionally most capable of protecting works with unclear or dubious copyright status is neither a private company like Google, nor a collective society like Authors Guild, arguably not even the state, which can design compulsory licensing schemes. It is rather the public as a whole, the same body that has an interest collectively in using and reusing information as input to new production. As Elinor Ostrom has demonstrated, studies "challenge the presumption that governments always do a better job than users in organizing and protecting important resources". ${ }^{70}$

Practically, what I propose is that this body of works shall be managed as commons along with the ones already in the public domain (following chapter). Successful management of commons is not a simple task. I propose that the central role of trust between key players (contributors, users and gatekeepers) shall be played by libraries, institutions that already enjoy a stern status and can be trusted to play the crucial role of gatekeepers for common intellectual recourses. The proposal needs further elaboration, which is beyond the scope of this article. Here I merely formulate the argument that current orphan and out-of-print works offer a great opportunity for institutional innovation with respect to commons.

\section{Public Domain Works}

The third category, public domain works, is rather the easier case when it comes to collection building for digital libraries. They are freed from copyright and available for scanning by any stakeholder, private or public, for the purposes of digitization. Quoting Paul Heald, the legal consequence of public domain status is that all users may appropriate freely without interference from competing claimants. ${ }^{71}$ Although there are many different definitions of the public domain (mainly depending on jurisdiction), most more or less accept at least this consequence as fact and as the common denominator. ${ }^{72}$

Commission Recommendation of 27 October 2011 on the digitization and online accessibility of cultural material and digitization preservation understands online accessibility of public domain works as follows (article 5):73 1.) It must be ensured that the material remains in the public domain after digitization; 2.) The widest possible access and reuse of the material for non-commercial and commercial purposes

\footnotetext{
68. A. Chander and M. Sunder (2004, p. 1338).

69. Ibid, p. 12.

70. E. Ostrom (2009, p. 409)

71. P. Heald (2014, p. 1).

72. For a consistent effort to map the public domain see P. Samuelson (2009).

73. See also Recital 13.
} 
must be promoted and; 3.) Measures to limit the use of intrusive watermarks or other visual protection measures that reduce usability of the digitized public domain material must be taken.

What does it mean, however, for the legislator or the policymaker to promote access and reuse of public domain works? Before looking at this question, we need to see why there is a need to promote access and reuse of the public domain in general; in other words, what is the value or the social utility of the public domain. According to Samuelson the public domain serves at least eight distinct values: it serves as 1.) building blocks for the creation of new knowledge and, 2.) enables competitive imitation, 3.) followon innovation, 4.) low-cost access to information, 5.) public access to cultural heritage, 6.) education, 7.) public health and safety, and last but not least, 8.) enables deliberative democracy. ${ }^{74}$ Paul Heald searching the same question of the value of maintaining a growing public domain draws an important conclusion: the value of the public domain will be its net value, which is the value generated by the work being in the public domain over and above what it would generate under copyright. ${ }^{75}$

Going back to the issue of the legislator promoting access and reuse of public domain works, the specific question this article focuses on is whether the existing legal framework assists or, at least, encourages libraries to provide this access and thus promote these values or benefits generated by the public domain. I believe that the current copyright framework and general copyright policy does not promote this access and reuse in a consistent and sufficient manner. Firstly, the copyright term is excessive, currently lifetime of the author plus 70 years on both sides of the Atlantic, blocking new important works from entering the public domain quicker after they have generated the necessary profits to the creator. The optimal scope of copyright for protected works is debated. It has also been famously modeled by W. M. Landes and R. A. Posner who concluded that because of discounting to present value, extensions of the copyright term beyond twenty or twenty-five years have little incentive effect for creators, which is the main rationale behind copyright laws in the first place. ${ }^{76}$ Existing formal models, however, tend to focus on the optimal term length for the recovery of sunk costs during a period of supra-competitive pricing, without considering the relevance of access and distribution of existing works or the costs imposed on follow-on creation and the other said values.

With an excessive copyright term, copyright policy is by definition not sided on the public domain side. Second, there is no copyright rule forbidding or disincentivizing the propertizing of public domain works. Thus, private companies are able to make profit out of this pool of sources offering them online as part of a service and locking them with DRM systems even though they are legally free from copyright. This is the case, for example, with Google, which began to scan books taken from libraries and also made public domain books part of their business plan for the Google Books service. Google profits from advertising, and thus offers the scanned public domain books for free to users; however it is part of a commercial service. There are additional examples of services that make profit directly from making available public domain works. ${ }^{77}$

\section{Conclusion: the need for a regulatory framework supporting online digital libraries and sustaining valuable knowledge commons}

The Internet's potential to revolutionize the way we access and then produce culture and knowledge should be supported by a regulatory framework that promotes wide accessibility, in order to sustain valuable commons supporting the ever-growing network ecosystem. Digital libraries are a central paradigm in this respect. Thinking about libraries, a helpful conceptualization is that of a zone of accessible

\footnotetext{
74. Samuelson, supra note 72, p. 22.

75. P. Heald (2014, p. 1), citing Pollock et al. (2010).

76. W. M. Landes and R. A. Posner (2003, p.70 and 210 et. seq).

77. See for example 〈http://www.forgottenbooks.org/>. At the same time, there are volunteer efforts involving assembling and offering public domain works for free, such as the Project Gutenberg (started in 1971 by Michael Hart) which is the first important online digital library project, exactly offering works that are free from copyright (under US law). The project now has over 45,000 items in its collection. See <http://www.gutenberg.org/> [Accessed: 19/05/14].
} 
information. ${ }^{78}$ It is necessary to enlarge the corpus of these accessible materials, if we believe in the value of creating and sustaining robust access points to knowledge online. Furthermore, within libraries, information is organized in a way meaningful to the users. As Randal Picker has noted (on the opportunity of the rejection of the Google Books Settlement in 2011) "we are at a point of rebooting how we design our digital library future". ${ }^{79}$ What already seems undesirable is a digital library monopoly. What we should instead want to foster is a rich digital library ecosystem. ${ }^{80}$

James Boyle describes the evolution of the Internet from a government project to the White Paper, to a private industry. ${ }^{81}$ The Internet has started from being an agora, then a market and now it returns to becoming an agora again. ${ }^{82}$ This becomes more clear when we look at Jonathan Zittrain's five conceptual layers to the network; physical; protocol; applications; content; and social layer. ${ }^{83}$ The layers represent the division of labor among people constructing and/or using the network. The past associates with proprietary networks and hierarchies, whereas the present facilitates polyarchies. Nowadays, however, we observe a cultural shift towards alternatives to either the market's contracts-based production (employers in firms) or property-based market- value systems (individuals in the market following signals). ${ }^{84}$ Other production models are mostly commons-based or peer-production models particularly visible in the digital world (for example open source software).

In the same vein, we observe a shift from strict and expanding copyright laws to peer production of knowledge, information and culture. ${ }^{85}$ Simultaneously, we witness the phenomenon of cultural agoraphobia (openness aversion) whereby we underestimate the "importance, viability, and productive power of open systems, open networks, and nonproprietary production." 86 This article seeks to be a basis for the consideration of the role of the digital library in fighting against this cultural agoraphobia. In the digital era space is virtually unlimited (information is stored in the cloud), knowledge is accessible and books are fireproof; libraries cannot turn to ashes like the library of Alexandria famously did. But how rich and accessible are they? How accessible can they be and how accessible should they be to the public? Indeed, the Internet's potential to revolutionize the way we access and then produce culture and knowledge should be supported by a regulatory framework sustaining online digital libraries, as public service institutions beyond markets and beyond the division of private and public.

\section{References}

BAND, J. (2009). "The long and winding road to the Google Books Settlement". 9J. The John Marshall Reviev of Intellectual Property. L. 227.

BENKLER, Y. (2002). "Coase's Penguin, or, Linux and The Nature of the Firm”. 112 Yale Law Journal, no. 369.

BENKLER, Y. (2006). The Wealth of Networks: How Social Production Transforms Markets and Freedom. Yale University Press.

BOYLE, J. (2008). The Public Domain: Enclosing the Commons of the Mind. Yale University Press.

CHANDER, A.; SUNDER, M. (2004). "The Romance of the Public Domain". 92 California Law Review, pp. 1331- 1373.

CHIARIZIO, M. (2013). "An American tragedy: e-books, licenses, and the end of public lending libraries?" Vanderbilt Law Review, vol. 66, no. 2, pp. 615-644.

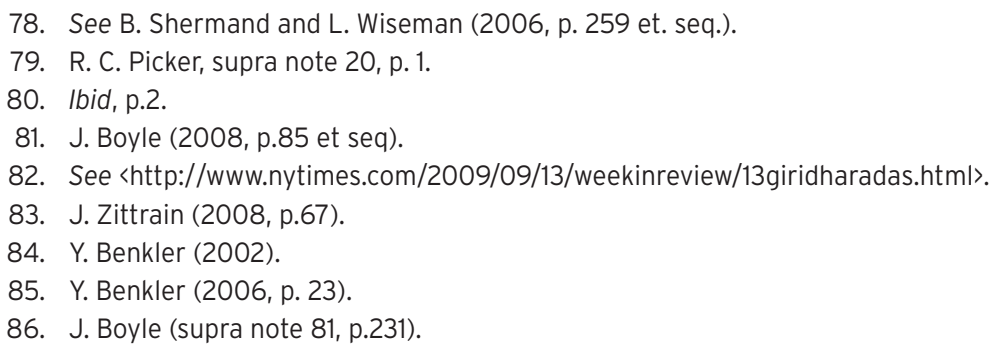


COHEN, J. E. (1996). "A right to read anonymously: a closer look at 'Copyright management' in: Cyberspace, Conn. L. Rev., no. 28, pp. 981-1039.

DALY, A. (2013). "E-book monopolies and the law". Media and Arts Law Review, no. 18, pp. 350 et. seq.

FAULHABER, G.; FARBER, D. (Oct. 2003). Spectrum management: Property rights, markets and the commons. Proceedings of the Telecommunications Policy Research Conference, Alexandria, VA. 〈http://rider.wharton.upenn.edu/ faulhabe/SPECTRUM_MANAGEMENTv51.pdf〉

FISCHMAN AFORI, O. (2013). "The battle over public e-libraries - tacking stock and moving ahead". IIC, no. 44, pp. 392-417.

GOLDSTEIN, P.; HUGENHOLTZ, B (2013). International Copyright, Principles, Law and Practice. Oxford University Press (3rd ed.).

HANSEN, D. (2011). Orphan Works: Definitional Issues, Berkley Digital Library Copyright Project White Paper \#1.

〈http://papers.ssrn.com/sol3/papers.cfm?abstract_id=1974614〉

HANSEN, D. (2012a). Orphan Works: Mapping the possible solution spaces, Berkley Digital Library Copyright Project White Paper \#2. 〈http://papers.ssrn.com/sol3/papers.cfm?abstract_id=2019121〉

HANSEN, D. (2012b). Orphan Works: Causes of the problem, Berkley Digital Library Copyright Project White Paper \#3.

〈http://papers.ssrn.com/sol3/papers.cfm?abstract_id=2038068〉

HEALD, P. (2014). "The public domain". In: R. WATT (ed.). The Law and Economics of Copyright Routledge. 〈http://papers.ssrn.com/sol3/papers.cfm?abstract_id=2362983〉

HUANG, O. (2006). “U.S. Copyright Office Orphan Works”. Berkley Technology Law Journal, no. 21, p. 265.

IVIR REPORT. Online uitlenen van e-books door bibliotheken.

〈http://www.ivir.nl/publicaties/poort/Online_uitlenen_van_e-books.pdf〉

KATZ, A. (2012). "The Orphans, the Market, and the Copyright Dogma: a modest solution for a grand problem". Berkeley Technology Law Journal, no. 27. 1285, pp. 1322-1331.

LANDES, W.M; POSNER, R.A. (2003). The Economic Structure of Intellectual Property Law. Harvard University Press.

LEMLEY, M. A. (1997). "Romantic authorship and the rhetoric of property". Texas Law Review, no. 75, p. 873.

MÜLLER, H. (2012). "Legal aspects of e-books and interlibrary loan". Interlending \& Document Supply, vol. 40, no. 3, pp. 150-155. 〈http://www.emeraldinsight.com/journals.htm?articleid=17047187〉

O'BRIEN, D.; GASSER, U.; PALFREY, J. (2012). "E-Books in Libraries: A Briefing Document Developed in Preparation for a Workshop on E-Lending in Libraries". Berkman Center Research Publication No. 2012-15. 〈http://papers.ssrn.com/sol3/papers.cfm?abstract_id=2111396\#\#〉

OSTROM, E. (2009). Beyond Markets and States: Polycentric Governance of Complex Economic Systems. Nobel Prize lecture.

〈http://www.nobelprize.org/nobel_prizes/economicsciences/laureates/2009/ostrom_lecture.pdf〉

PALLAS LOREN, L. (2012). "Abandoning the Orphans: An Open Access Approach to Hostage Works". Berkeley Technolohy Law Journal, no. 27. <http://papers.ssrn.com/sol3/papers.cfm?abstract_ id=2049685>

PERZANOWKSI, A; SCHULTZ, J. (2011). “Digital Exhaustion”. UCLA Law Review, no. 58, pp. 889-946.

PICKER, R. C. (2011). "After Google Book Search: Rebooting the Digital Library". John M. Olin Program in Law and Economics. Working Paper No. 559. 
POLLOCK, S., Valimakki, M. (2010). "Valuing the EU Public Domain". Cambridge Working Papers in Economics, no. 1047, pp. 1 - 54.

REESE, R. A. (2003). "The first sale doctrine in the era of digital networks". Boston College Law Review, vol. 44, no. 9., p. 577.

ROSENBLATT, B. (2012). "A Nail in Public Libraries' Coffins". Copyright and Technology [online]. <http:// copyrightandtechnology.com/2012/05/20/a-nail-in-public-libraries-coffins/>

SAMUELSON, P. (2006). "Challenges in Mapping the Public Domain". In: L. GUIBAULT and P. B. HUGENHOLTZ (eds). The Future of the Public Domain: Identifying the Commons in Information Law, pp. 7-25.

SAMUELSON, P. (2009). Google Book Search and the future of Books in Cyberspace. Minnesotta Law Review, no. 94, p. 1308.

SALZBERGER, E. (2006). "Economic Analysis of the Public Domain". In: L. GUIBAULT and P.B. HUGENHOLTZ (eds). The Future of the Public Domain, pp. 27-58.

SHERMAN, B.; WISEMAN, L. (2006). "Toward an Indigenous Public Domain?". In: L. GUIBAULT and P.B. HUGENHOLTZ (eds). The Future of the Public Domain: Identifying the Commons in Information Law. Kluwer, p. 259.

SMITH, M. D.; TELANG, R.; ZHANG, Y. (2012). Analysis of the Potential Market for Out-of-Print eBooks. $\langle$ http://ssrn.com/abstract=2141422〉

US COPYRIGHT OFFICE (2011). Legal issues in Mass Digitization: a preliminary analysis and discussion document. Office of the register of copyrights. <http://www.copyright.gov/docs/massdigitization/ USCOMassDigitization_October2011.pdf>

VAN GOMPEL, S.; HUGENHOLTZ, B. (2010). "The orphan works problem: the copyright conundrum of digitizing large scale audiovisual archives, and how to solve it". Popular Communication. The International Journal of Media and Culture, Vol. 8, No. 1, pp. 61-71. 〈http://www.ivir.nl/publications/vangompel/the_orphan_works_problem.pdf〉

ZITTRAIN, J. (2008). The Future of the Internet -- And How to Stop It. Yale University Press \& Penguin UK. 


\title{
Recommended citation
}

PANEZI, Argyri (2014). "Legal Challenges for Online Digital Libraries". IDP. Revista de Internet, Derecho y Política. No. 19, pp. 18-34. UOC. [Accessed: dd/mm/yy].

〈http://journals.uoc.edu/index.php/idp/article/view/n19-panezi/n19-panezi-en〉

$\langle$ http://dx.doi.org/10.7238/idp.v0i19.2423〉

The texts published in this journal, unless otherwise indicated, are subject to a Creative Commons Attribution-NoDerivativeWorks 3.0 Spain licence. They may be copied, distributed and broadcast provided that the author, the journal and the institution that publishes them (IDP Revista de Internet, Derecho y Política; UOC) are cited. Derivative works are not permitted. The full licence can be consulted on http://creativecommons.org/licenses/bynd/3.0/es/deed.en.

\author{
About the author \\ Argyri Panezi \\ Ph.D. Candidate \\ European University Institute, Department of Law (Florence) \\ argyri.panezi@eui.eu
}

Argyri Panezi is a PhD candidate at the European University Institute in Florence. Her topic is the law and economics of book digitization, and in particular she researches the legal challenges posed by the creation of digital libraries and the regulation of knowledge commons in networked environments. She obtained her LL.M. at Harvard Law School where she specialised in Internet law and policy. She obtained her undergraduate law degree from the University of Athens, Greece, and was called to Bar in Athens in 2011. Prior to her doctoral studies, she worked as an attorney in Brussels.

European University Institute

Badia Fiesolana

Via dei Roccettini 9,

I-50014 San Domenico di Fiesole (FI)

Italy

\section{$\bullet$ UOC \\ Universitat Oberta \\ de Catalunya}

